\title{
VARIEGATED INTERSECTIONS OF NEOLIBERALISM AND FINANCIALIZATION
}

\section{Introduction to Themed Issue of EPA: Economy and Space, on Intersections of Financialization and Neoliberalism}

Chris Muellerleile and Shaun French

October, 2021

Decades into a climate disaster, 12 years after the worst financial crisis in a century, and 18 months into a global pandemic, it is perhaps a cliché to say that we are living through turbulent political-economic times. In a period of true uncertainty (Mann 2020), characterising the state of capitalism, let alone predicting its future, is fraught with danger. At the same time, and as has been argued many times before, crises open up the taken for granted and create critical space for thinking the world otherwise in important ways; notwithstanding, of course, the risks of perpetuating a reading of capitalist crisis as exception (Christophers et al. 2017). In our case, we are interested in a more just social and economic future where finance capital and neoliberal dogma are less influential than they have been for the last 40 years. We are of course not alone in this desire but how exactly to achieve this future is the subject of intense debate, not least in the pages of Economy and Space.

Over the last several years of upheaval, various scholars have attempted to characterise the economic condition of the Global North. Adkins et al. (2020) argue we are locked into an "asset economy", fuelled mainly by inflation in house prices, and which is reworking class and party allegiances. Christophers (2020) argues that state supported monopoly and market power in many sectors, is a manifestation of a new period of "rentier capitalism", not least in the U.K. Highlighting both the resiliency of state entanglements in capitalist economies as well as the geopolitical and geoeconomics imaginaries of international competition, Alami and Dixon (2019, 2020) argue that "state capitalism" is another way to make sense of the current political economic conjuncture. Attempting to make sense of the emotional charge of economic struggles in the wake of 40 years of neoliberal restructuring, Blyth and Lonergan (2020) characterize this as the age of "angrynomics". Considering the relationship between the rise of nationalism, authoritarianism, and capitalism, Hendrikse (2021) labels the contemporary moment as "neoilliberal". Dean (2020) sees similar trends but questions whether the system remains capitalist at all, suggesting it might better be understood as "neo-feudalism". Blakeley (2020) resurrects Lenin's and Hilferding's "state-monopoly capitalism" to explain the implications of direct state intervention in the wake of Covid-19, and Fraser sees capitalism increasingly turning inward, 
cannibalizing its own conditions of possibility (2021). Lazzarato (2021; Alliez and Lazzarato, 2016) goes further, suggesting that $21^{\text {st }}$ century capital, fuelled by racism and fascism, has entered a self-destructive war-machine phase bent on widespread destruction.

There are countless other attempts to make sense of contemporary capitalism, and of course there are similarities and important differences between the accounts we have mentioned. But for the purposes of this short introduction, what is most interesting to us is that all of these accounts include significant interrogations of the recent history and/or the current role of both financialization and neoliberalism. In many ways this is not surprising given that, along with globalization, digitization, and climate change, these are arguably the most transformative political economic forces of the last 30 to 40 years. At the same time, none of the above accounts provide an explicit analysis of exactly how neoliberalism and financialization differ, intersect, overlap, consolidate or fracture, other than to state that in various ways, they do. This is not a criticism (that would be unfair given the brevity of our engagement!), but rather an observation, and exemplary of what we see as a gap in research in economic geography and related disciplines.

This was the point of departure for this themed issue, and the conference sessions that preceded it. ${ }^{1}$ That is, the issue emerged as a result of our general dissatisfaction with the existing literature for its lack of explicit analysis of the historical and contemporary intersections of financialization and neoliberalism. There are exceptions, some of which we mention below, but too few. There is also no question that these two forces and ideas are "mutually reinforcing" (Walks and Clifford 2015: 1625), which innumerable studies in critical political economy demonstrate. Yet, not enough attempts have been made to disentangle the fractured and at times contradictory history of their co-emergence, or consider how rethinking them might change our perspective on the current conjuncture that is prima facie a transformative moment in economic history (Mann 2020).

One way this has been attempted is to differentiate neoliberalism, as an -ism, or a set of ideas, while framing financialization as an-ization, or a material or historical process. A similar way of differentiating them is to imagine neoliberalism as largely taking form in the sphere of politics, governance, regulation, and law, whereas financialization takes form in material processes, largely in relation to the production and exchange of value in the sphere of economics. However, any cursory reading of the literature on either concept, including the three empirical papers published

\footnotetext{
${ }^{1}$ In what seems like a lifetime ago, this conversation began with two paper sessions at the August, 2016 Royal Geographic Society-Institute of British Geographers' annual conference in London.
} 
here (cite this issue, Horton, Byrne \& Norris, Fields), will quickly find these boundaries traversed.

One might argue that the lacuna we highlight here is one based on misguided labelling or is simply a set of category errors. In other words, perhaps the labels of financialization or neoliberalism, or both, have outlived their usefulness? And regardless, properly understanding their histories and present states requires looking beyond explicit interrogations of these concepts. The latter is undoubtedly true, but we still find these two concepts useful even if both defy simple definitions (on financialization see Aalbers 2015, Ioannou \& Wojcik 2019, on neoliberalism see Brenner et al. 2010), and as with all theories their explanatory power has its limits. As such, in addition to ongoing debate over their usefulness in relative isolation, we think there is much value in explicitly interrogating the relationship between them. We will return to this below along with some thoughts on why geographers are well positioned to make these contributions, but first it is worth considering some of the existing literature that has explored this relationship.

When they are clearly differentiated and compared, there is a tendency amongst scholars, we argue, to subsume one process to the other, even if that subsumption is not made explicit. Dumenil and Levy (2004), take a relatively orthodox Marxist political economic approach, where the economically basic process of finance-based accumulation is supported by the superstructural legitimacy provided by neoliberalism. Not unlike Harvey's account (2005), the latter largely serves as a set of hegemonic ideas serving the capitalist and managerial classes, but also a set of ideas that has only become dominant because of the deep structural or material crisis of embedded liberalism. In Dumenil and Levy's account, the resurgent power of capital to subordinate labour since the early 1970s has been dominated by finance, and the state has had little choice but to support financial sector interests, all of which is justified by neoliberal ideology.

Kotz (2011) sees the historical relationship differently, arguing that too much emphasis on finance is a mistake. Contra Krippner (2011), he suggests that influential neoliberal thought preceded the first major U.S. banking and financial deregulatory moves of the early 1980s. For Kotz, the institutionalism of Keynesianism or "regulated capitalism", had to give way to neoliberalism, qua a new social structure of accumulation, before finance could be set free. As such, he argues not only that financialization happened after neoliberalism, but that financialization cannot explain institutional change the way neoliberalism can.

Far from subsuming one to the other, Fine, along with various collaborators, has provided some of the most nuanced discussion of the relationship between financialization and 
neoliberalism (Fine 2012, Fine and Hall 2012, Fine and Saad-Filho 2017), and has also contributed a commentary to this themed issue (cite Fine this issue). Fine and Saad-Filho (2017: 686) define neoliberalism as a "material structure of social, economic and political reproduction underpinned by financialization" (emphasis in original). Frequently referring to financialization as "underpinning", or as the "material basis" for neoliberalism, the authors are critical of strands of Marxism that overlook "the role of financialization ... in promoting and supporting the contemporary (neoliberal) forms of accumulation and the social reproduction that accompanies it" (Fine and Saad-Filho, 2017: 689). This they argue is the product of a functionalist tendency within Marxist thought that reduces financialization to a second order effect of the "still unresolved crisis of Keynesianism" (ibid: 689, emphasis in original). There are parallels in this critique with the accounts of scholars such as Marazzi (2008, 2014) and Lapavitsas (2013) who have similarly stressed the need to understand financialization as an integral feature of a systematic transformation of present-day capitalism, rather than a relatively short-term, if not repetitive, response to a crisis of productive capital, as exemplified by Arrighi's (1994) argument. For instance, Fine and Saad-Filho (2017) observe that financialization is characterised by an expansive role for finance as interest-bearing capital, and marked by capital mobility, the influence of shareholders, low inflation and monetarism. And despite suggesting a "common core" they stress there is a need to interrogate the contradictions between neoliberalism and financialization.

Through this, Fine and colleagues question the common subsumption - implicit or otherwise - of financialization to more general neoliberalising tendencies. Still, Fine and SaadFilho's (2017) do rely on a dualistic framing that contrasts neoliberalism as ideology against financialization as materiality. This is evident not only in the language of 'underpinning' and 'material basis' but also in such phrases as the "secular rise of financialization" (Fine and SaadFilho, 2017: 696). Even if this dualism is not dominant, it is recurrent across the literature, including in geography. For instance, Ward and Swyngedouw (2018) draw a distinction between neoliberalisation as a "political restructuring ethos" and "ideational framework", on the one hand, and financialization as the "dominance of financial markets" on the other hand.

Krippner's (2011) rich account of the history of financial deregulation and of the evolution of U.S. monetary policy in the 1970s and 1980s foregrounds the importance of finance in the emergence of market rule. Noting that the turn to the market "achieved its fullest expression in the processes I have explored under the rubric of financialization”, Krippner's (2011: 138) account of the political origins of the rise of finance is one mostly shorn of ideology. Central to Krippner's thesis is the argument that financialization in the U.S. emerged 
"inadvertently" (2) as the result of other political or distributional questions and crises, particularly associated with the effects of inflation. Save for fleeting references to neoliberal policymakers and what are described as a "few isolated proponents of the new laissez-faire economics" (ibid: 141), this is a history that is determined by the ad hoc, reactive and seemingly non-ideological responses of politicians and regulators to both an economic crisis and the inability of democratic politics to resolve distributional conflicts that were made starkly legible by the bouts of inflation in the 1970s. Neoliberalism and financialization in Krippner's account could be described as a "state-centered form of bricolage" (Walks and Clifford 2015: 1625), which is reminiscent of Engelen et al's (2011) analysis of the makeshift, state regulatory approach to financial markets in the 1990s and 2000s, and which led directly to the 2007-9 crisis. In this issue, Byrne and Norris tell a similar story about the contingent policy layering resulting in the marketization of social housing in Ireland over the last 40 years.

Focusing on the overlapping, recent history of neoliberalism and financialization in the U.K., Davis and Walsh $(2016,2017)$ juxtapose the world views of "financiers" with "neoliberal politicians and economists", but they also demonstrate how these groups intersect in practice. They draw a distinction between the particular and practical financial market concerns of the financiers, and the more wide-ranging, macro concerns of neoliberals. They observe, for example, that whereas "neoliberal economists and politicians embrace the broadening of markets and marketization of so many aspects of life", in contrast "financiers remain relatively fixated on financial markets" (Davis and Walsh, 2017: 33). Otherwise, the distinctions they draw between financialization and neoliberalism are less clear, but they make an astute point about the embodiment of these ideas and processes. The revolving door of expertise between City of London financial elites, the Treasury, and the Department of Trade and Industry (DTI) in the period 1976-2010, was critical to shaping neoliberal Britain. It was through this movement of people, that financier thinking was able to exercise such a deep structuring effect on the shape of neoliberalism - mainly in privileging financial logics, actors, firms, and most importantly the finance sector over U.K. industry, even when contradictory to neoliberal dogma.

As implied above, this is by necessity a partial reading of the scholarship on this interrelation. A broader interpretation of the history of financialization and neoliberalism, or one where that relationship was not explicitly interrogated, would quickly reveal a vast library of relevant literature, including many contributions in this journal, and the same exercise in broadening would also likely lead back to the question posed earlier, whether these specific concepts retain explanatory power and deserve to be treated as relevant. One way to keep this 
question front and centre without abandoning said concepts is by treating them both as variegated.

\section{Variegated intersections}

Rather than positioning one as an ideational project and the other as a material or historical process, the three substantive papers here analyse both financialization and neoliberalism as contextualized processes, driven at the same time by ideas and materiality. Put differently, they consider the politics of finance along with the materiality of neoliberalism. This might be interpreted as researching actually existing neoliberalism or what Brenner, et al. (2010) refer to as "neoliberalization" that is, neoliberalism as a process, even if this formulation does not necessarily include consideration of financial processes.

A similar way to rethink this intersection is through the concept of variegation, which in geography was originally applied to capitalism and neoliberalism (Peck and Theodore 2007, Brenner et al. 2010), but has more recently been employed in relation to financialization (Lai 2017, Dixon 2011, Aalbers 2017) and has not received as much attention. Variegated financialization requires an appreciation of how financial practices, logics, markets, and actors manifest differently and always incompletely across a diversity of socio-spatial contexts, economic sectors, and institutional path dependencies. Similarly, this approach to financialization is attendant to its construction from the 'ground up', with a hesitancy to make claims about the universalizing logic or reductive power of exchange value or the cash nexus. "Approaching" financialization (French et al. 2011) this way; as a contingent process that is often resisted, if not reshaped by institutions and individual subjects, which is never an easy methodological task, becomes even more tricky when variegated neoliberalization is considered at the same time. But crucially, a variegated approach to financialization or neoliberalism should not be interpreted as attempts to over-rely on contingency and contradiction in isolated and localized conditions. It is also an attempt to understand geographic interconnections, common processes of policy development, and patterns of institutional change.

Put differently, variegation as a methodological approach is not only about identifying difference, contingency and disconnected instance, but also interconnection, tendential change, and common reference points. Identifying exactly what these commonalities are is not easy, but perhaps for neoliberalism, it is the perceived virtue of, and policy mandates related to competition or marketization. For financialization, it is tempting to point toward the reductive cash nexus, the influence of fictitious capital, or the repetitive historical tendency of capital to 
'switch' into the accelerated temporal mode of reproducing exchange value without the longerterm commitments required for 'real' production (Vercelli 2014). The difference from a more conventional structural approach is that variegation mandates rigorous and repetitive engagement with the constitutive and agential parts that make up and contest the elusive, and perhaps non-existent quintessence. Another way to think about this is that the concepts themselves, neoliberalism and financialization, continue to have explanatory power, if only as abstractions that require constant interrogation through the comparison of concrete case studies, including historical investigations (for an extended analysis in relation to neoliberalism, see Peck 2013).

Given the complex methodological implications of a variegated approach to either neoliberalism or financialization, we are setting a high standard in suggesting that researchers consider both at the same time. What makes this relationship so complex? It is precisely because these two processes tend to be entangled with one another, and that one is invariably a crucial component of the variegation of the other. Would it not then be easier to leave one of the two as a control, whilst testing the other as a dependent variable? In fact, it may. Perhaps a less daunting way to think about this intersection is the analysis of neoliberalization and financialization as two co-constitutive processes. Regardless, as the wide variety of rich empirical investigations, often explicitly informed by various theories of neoliberalism or financialization, and sometimes both, in this and other geographically-oriented journals demonstrate, this kind of analysis is certainly possible, and we encourage more of it, if only on more explicit terms. The three substantive articles that make up this themed issue, are one place to look for a model of this kind of research. All three take seriously the contingent intersection of financial and neoliberal processes, even if they do not explicitly make use of the concept of variegation, let alone the variegation of the intersections.

Horton's timely paper (cite this issue) analyses the effects of state austerity and the growing influence of private equity on labour in the social care sector in the U.K. Horton points out the intersection of a neoliberal predisposition towards care, but one that emerged after financial pressure on hybrid public-private care homes materialized beginning in the 1970s. This leads to more full-scale privatization as private equity, and the associated competitive market pressure squeeze care homes' bottom lines. Much of this pressure is felt by labourers, who are disproportionately women and ethnic minorities, but these carers also resist the pressure of the competitive logic, and as such limit the effects of financialization by working harder for patients. Interestingly, the other two papers in the issue consider housing, but Horton demonstrates the importance of real estate finance, given that one of the first steps taken by investment funds 
when they buy up a social care facility or chain of facilities is to sell off the real estate and buildings, and then lease them back from the new owners. This asset stripping makes the finances of care homes even more precarious, subject to unpredictable increases in rent.

Fields's paper (cite this issue) explores the capitalization of the housing rental market in the U.S. Employing the concepts of extractive and logistical 'operations', Fields focuses on the various ways that digital technologies, algorithms, and platforms enable the construction of a new asset market in what was previously considered a financial "backwater", and in the process exacerbate inequality in housing. The context is the post-global financial crisis search for new frontiers of financial accumulation, which fuelled socio-technical experimentation, new forms of surveillance of renters and service laborers, and ultimately attempts by companies to buy up single family homes for the purpose of streamlining and vertically integrating a financial supply chain actively extracting a regular flow of rental payments.

Byrne and Norris examine the fluctuations of the value of homes in Ireland over the last twenty years, and explain this by showing how the Irish housing sector, both socialized and private, has become deeply entangled with cycles of credit availability and financial boom and bust. This has taken place in the context of widespread liberalization of housing finance in Ireland in the 1980s, and entrance into the Eurozone in 1999. At the same time, and not unlike Fields's case in the U.S., Byrne and Norris show us how rental homes in Ireland, formally heavily subsidized by the state, increasingly constitute a new securitized asset class. The exact character of neoliberalization in this case, however, is highly contingent on the "subtleties and complexities" of national and historical conditions of Ireland. Rather than a directed set of policies driven by a coherent ideology, neoliberalized housing happened through policy layering, and attempts by the state to solve interrelated problems over time.

We will not summarize Fine's short, but very helpful commentary on the three papers other than to say that he raises important and provocative questions, as well as helpfully contextualizing the themed issue in some of the most recent debates over the nature of financialization, not least in the context of the Covid pandemic.

The 2007-9 financial crisis certainly did not put an end to processes of financialization or neoliberalisation, but it is difficult to deny that the crisis changed their course. The financial sector has since entered yet another stage of experimentation, searching out new asset classes (see, for example, Beaverstock et al. 2021 on Collateralized Loan Obligations), in what Aalbers and Engelen (2015: 1597) call the "the rise and fall and rise again of securitization". Neoliberalism, having lost much of its legitimacy, seems to be more fractured and authoritarian than ever in the wake of 2007-9, not to mention Brexit and Trumpism, but it nevertheless 
continues to reproduce it's variegated form (Slobodian 2019, Peck and Theodore, 2019). As many of the authors referenced at the outset of this essay argue, the Covid pandemic has resulted in another capitalist phase transition, but exactly how this will develop unevenly across space, and how the changes wrought by a global pandemic will collide with the political economy of climate change and its mitigation are just beginning to take shape (see, for example, Tooze, 2021). We suspect a fruitful methodological approach to making sense of these transformations will be to pay close attention to the future variegated intersections of financialization and neoliberalization.

\section{References}

Aalbers, M. (2015) “The potential for financialization”, Dialogues in Human Geography, vol. 5, iss. 2

Aalbers, M. (2017) "The variegated financialization of housing", International Journal of Urban and Regional Research, v. 41, iss. 4

Aalbers, M. and Engelen, E. (2015) “Guest commentary" Environment and Planning A 2015, volume 47, pages $1597-1605$

Adkins, L., Cooper, M., and Konings, M. (2020) The Asset Economy, Cambridge: Polity

Alami, I. and Dixon, A.D. (2020) “The strange geographies of the 'new' state capitalism, Political Geography, vol. 82, iss.

Alliez, E. and Lazzarato, M. (2016) Wars and Capital, LA: Semiotext(e)

Arrighi, G. (1994) The Long Twentieth Century: Money, Power and the Origins of Our Time, London: Verso,

Beaverstock, J., Leaver, A. and Tischer, D. (2021) 'How financial products organize spatial networks: Analyzing collateralized debt obligations and collateralized loan obligations as 'networked products", Environment and Planning A: Economy and Space.

Blyth, M. and Lonergan, E. (2020) Angrynomics, Newcastle: Agenda Publishing

Brenner, N., Peck, J. and Theodore, N. (2010) "Variegated neoliberalization: geographies, modalities, pathways, Global Networks, v. 10, iss. 2: 182-222, https://doi.org/10.1111/i.1471$\underline{0374.2009 .00277 . x}$

Christophers, B. (2020) Rentier Capitalism, Brooklyn: Verso

Christophers, B., Leyshon, A. and Mann, G. (2017) Money and Finance After the Crisis: Critical Thinking for Uncertain Times, Oxford: Wiley Blackwell 
Davis, A. and Walsh, C. (2016) "The role of the state in the financialisation of the UK economy", Political Studies, 64(3): 666-682

Davis, A. and Walsh, C. (2017) "Distinguishing financialization from neoliberalism", Theory, Culture \& Society, 27(5-6): 27-51

Dean, J. (2020) "Communism or Neo-Feudalism", New Political Science, 10.1080/07393148.2020.1718974

Dixon, A.D. (2011) "Variegated capitalism and the geography of finance: Towards a common agenda", Progress in Human Geography, vol. 35, iss. 2

Dixon, A.D. and Ilami, I. (2020) "State capitalism(s) redux? Theories, tensions, controversies", Competition and Change, vol. 24, iss. 1

Dumenil, G. and Levy, D. (2004) Capital Resurgent: Roots of the Neoliberal Revolution, Cambridge, MA: Harvard University Press

Engelen, E., Erturk, I, Froud, J., Sukhdev, J., Lever, A., Moran, M., Nillson, A. and Williams, K. (2011) After the Great Complacence, Oxford: Oxford University Press

Fine, B. (2012) 'Neoliberalism in Retrospect? It's Financialization, Stupid”, included in KyungSup, C.,Fine, B. and Weiss, L. (eds.) Developmental Politics in Transition: The Neoliberal Era and Beyond, Basingstoke: Palgrave Macmillan

Fine, B. and Saad-Filho, A. (2017) 'Thirteen things you need to know about neoliberalism', Critical Sociology, 43(4-5); 685-706

Fraser, N. (2021) "Climates of Capital: For a Trans-Environmental Eco-Socialism”, New Left Review, vol. 127, Jan-Feb

French S, Leyshon A and Wainwright T (2011) "Financializing space: spacing financialisation Progress in Human Geography, 35: 798-819

Harvey, D. (2005) A Brief History of Neoliberalism, Oxford: Oxford University Press

Hendrikse, R. (2021) “The Rise of Neo-illiberalism”, Krisis, 41,1: 65-93

Ioannou, S. and Wojcik, D. (2019) "On financialization and its future", EPA: Economy and Space 2019, Vol. 51(1) 263-271

Kotz, D.M. (2011) 'Financialization and Neoliberalism', in G. Teeple and S. McBride (eds), Relations of Global Power: Neoliberal Order and Disorder, Toronto, University of Toronto Press, pp. 118

Krippner, G.R. (2011) Capitalizing on Crisis, Cambridge, MA: Harvard University Press

Lai, K. (2017) "Financial advisors, financial ecologies and the variegated financialisation of everyday investors" Transactions of the Institute of British Geographers, vol. 41, iss. 1 
Lapavitsas, C. (2013) Profiting Without Producing: How Finance Exploits Us All, London, Verso

Lazzarato, M. (2021) Capital Hates Everyone, South Pasadena: Semiotext

Mann, G. (2020) "Irrational Expectations", Viewpoint Magazine, April 29, accessed here on 10/19/21: https://viewpointmag.com/2020/04/29/irrational-expectations/

Marazzi, C. (2008) Capital and Language: From the New Economy to the War Economy, Los Angeles, Semiotext(e)

Marazzi, C. (2014) The Linguistic Nature of Money and Finance, Los Angeles, Semiotext(e)

Peck, J. (2013) “Explaining (with) Neoliberalism”, Territory, Politics, Governance, vol. 1, No. 2, 132 157

Peck and Theodore (2007) "Variegated Capitalism", Progress in Human Geography, vol. 31, iss. 6

Peck and Theodore (2019) "Still Neoliberalism?", The South Atlantic Quarterly 118:2, April 2019 doi 10.1215/00382876-7381122

Slobodian, Q. (2019) “Anti-'68ers and the Racist-Libertarian Alliance”, Cultural Politics, Volume 15 , Issue 3

Tooze, A. (2021) Shutdown: How Covid Shook the World's Economy, New York: Viking

Vercelli, A. (2014) "Financialization in a Long-Run Perspective", International Journal of Political Economy, vol. 42, no. 4, Winter 2013-14, pp. 19-46.

Walks, A. and Clifford, B. (2015) "The political economy of mortgage securitization and the neoliberalization of housing policy in Canada", Environment and Planning A 2015, volume 47, pages $1624-1642$

Ward, C. and Swyngedouw, E. (2018) 'Neoliberalisation from the ground up: Insurgent capital, regional struggle, and the assetisation of land', Antipode, 50(4): 1077-1097 